\title{
Anxiety levels of community pharmacists during the COVID-19 pandemic: a cross- sectional study in Istanbul
}

\section{COVID-19 pandemisi sürecinde serbest eczaciların anksiyete düzeyleri: İstanbul'da bir kesitsel araştırma}

\author{
Hüseyin Küçükali ${ }^{1 *}$ \\ ORCID: 0000-0003-1669-3107 \\ Osman Hayran ${ }^{1}$ \\ ORCID:0000-0002-9994-5033 \\ Ezgi Duman ${ }^{1}$ \\ ORCID:0000-0003-4015-7232 \\ Ayyüce Karaca ${ }^{1}$ \\ ORCID:0000-0001-8177-6334 \\ Aylin Kirikçi ${ }^{1}$ \\ ORCID:0000-0002-8477-2344 \\ Onur Çiftçi ${ }^{1}$ \\ ORCID:0000-0002-6713-9176
}

${ }^{1}$ Istanbul Medipol University, School of Medicine, Department of Public Health, 34815, Beykoz, Istanbul, Turkey

\section{Corresponding author:}

Hüseyin Küçükali

Istanbul Medipol University, School of Medicine, Department of Public Health, Goztepe Mah. Ataturk Cad. No:40/16 34815 Beykoz, Istanbul, Turkey

Tel: +90 $2166815100(2203)$

Fax: +902125212377

Email: hkucukali@medipol.edu.tr
DOI: 10.52794/hujpharm.988353

\begin{abstract}
Community pharmacists have been on the frontlines during the 2019 Coronavirus Disease (COVID-19) pandemic. Although the mental health and anxiety levels of many other health workers are studied in this period, literature is very limited to understand the experience of pharmacists. This study aims to define the anxiety level of community pharmacists in Istanbul during the COVID-19 pandemic and identify possible influencing factors. The population of the study is community pharmacists from pharmacies in Istanbul. In this cross-sectional study, 348 pharmacies are selected by simple random sampling. Participants are approached via telephone and inquired with questions about sociodemographic information, work conditions, COVID-19 specific concerns, and the Beck Anxiety Inventory. $239(68.7 \%)$ pharmacists responded. This study identifies that, by the 6th month of the pandemic, the mean anxiety score of the pharmacists in Istanbul is $9.4 \pm 10.6$, and $54.8 \%(\mathrm{n}=134)$ of the participants is experiencing "minimal" anxiety. However, they have some COVID-19 specific concerns (becoming infected and transmitting the disease to family or environment) at high and extreme levels. Those concerns significantly increase the anxiety score. The findings of this study are promising for public health, as they show that community pharmacists could cope with the psychological effects of the pandemic.
\end{abstract}

Keywords: Anxiety; COVID-19; Mental Health; Community Pharmacists

\section{ÖZET}

Eczacılar, 2019 Koronavirüs Hastalığı (COVID-19) pandemisi döneminde sağlık hizmetlerinin ön saflarında çalışmaktadır. Bu süreçte hastalarla birebir temas halinde olmaları ve çalışma şartlarındaki değişiklikler ruhsal iyilik hallerini etkileyebilir ve anksiyeteye sebep olabilir. Alanyazında COVID-19 pandemisi sürecinde, diğer sağlık çalışanlarının ruhsal iyilik halleri ve anksiyete düzeylerine ilişkin araştırmalar mevcut iken araştırmalar eczacıların deneyimini anlamak için yetersizdir. Bu çalışmanın amacı, COVID-19 pandemisi sürecinde İstanbul'da görev yapmakta olan eczaciların anksiyete düzeyini ve onu etkileyebilecek faktörleri tespit etmektir. Araştırmanın evreni İstanbul'daki eczanelerde görev yapan serbest eczacılardır. Kesitsel türdeki bu araştırmada basit rastgele örnekleme yöntemi ile 348 eczane seçilmiştir. Seçilen eczanelere telefon ile ulaşılıp; sosyodemografik bilgiler, çalışma bilgileri ve COVID-19'a özgü endişeler hakkında 
sorular ile Beck Anksiyete Ölçeği maddeleri yöneltilmiştir. Örnek gruptaki eczacıların \%68,7'ine (n=239) ulaşılmıştır. Pandeminin 6. ayı itibariyle İstanbul' daki eczacıların anksiyete ölçeği puanı ortalamasının 9,4 $\pm 10,6$ olduğu ve \%54,8'inin ( $\mathrm{n}=134$ ) “minimal düzeyde anksiyete” sahibi olduğu tespit edilmiştir. Bununla beraber COVID-19'a özgü bazı endişelerinin (hastalığa yakalanma ve çevresine bulaştırma) çok ve aşırı çok hissedildiği ve bu endişelerin genel anksiyete puanını istatistiksel olarak önemli düzeylerde etkilediği tespit edilmiştir. Bu sonuç, eczacıların psikolojik olarak pandemiyle başa çıkabildiklerini göstermesi itibariyle halk sağlı̆̆ açısından ümit verici olarak yorumlanabilir.

Anahtar kelimeler: Anksiyete, COVID-19, Eczac1, Kayg1, Ruh Sağlı̆̆1

Infectious diseases are still among the leading causes of mortality and morbidity despite the gains in global health in the last decades. Infectious disease outbreaks not only make individuals sick but also negatively affect their mental health [1].

In December 2019, a new type of coronavirus emerged in the city of Wuhan in the Hubei province of China. The virus which is called SARS-CoV-2 [2] is a contagious virus that causes acute respiratory tract infection and can be transmitted from human to human [3]. The COVID-19 disease caused by the virus was declared as an "International Public Health Emergency" at the meeting of the World Health Organization held on January 30, 2020 [4]. The pandemic was declared on March 11, 2020 [5]. The first case in Turkey was seen on March 11, 2020.

Since healthcare workers were at the frontline of pandemic response [3], they faced many risks due to the working conditions [6]. Healthcare workers are known to be one of the high-risk groups in terms of infection transmission [7]. Besides, they are susceptible to stressors specific to the pandemic such as fatigue, self-isolation due to work, and lifestyle changes in a short time [8]. During the COVID-19 pandemic, health professionals had to cope with mental health problems along with physical fatigue [9]. These mental health problems may cause a reduction in the health workforce [3] and disrupt the services while it is needed at most. The negative effects of the pandemic on mental well-being also affect the quality of patient care $[3,7,8,10]$. Healthcare workers have to constantly use personal protective equipment such as masks and overalls while serving infected, contacted or suspected patients [7]. Using these pieces of equipment makes the work of healthcare professionals even more difficult. A study on SARS showed that health care workers who were involved in the treatment of infected patients had higher anxiety scores than those who were not [7].
Pharmacists are health professionals who ensure the continuity of care. They may be seen as the providers of the most accessible health service to the patients. Pharmacists usually step into the care process after diagnosis [11] and contact regularly with patients. During the pandemic, community pharmacists had to adapt to completely new working conditions which involve physical arrangements inside the pharmacies (protective barriers, and limiting the number of concurrent customers) to reduce the risk of transmission [12].

In addition to doctors and nurses who are working in the hospitals during the pandemic period, pharmacists also can be considered working on the frontline since they mostly work more closely with the community. They face a variety of difficulties. Since they have direct contact with patients, the foremost difficulty is the risk of infection and being a carrier [5]. Others can be listed as long working hours, increased workload, difficulties in drug supply and procurement, inability to access protective equipment, financial difficulties, and social exclusion [7]. Also, anxious or nervous patients may affect pharmacists [3]. Those factors can increase the stress and anxiety experienced by pharmacists [3].

Pharmacists take an active role in many areas of the health system during the pandemic. Some of these are to consult and redirect patients with symptoms, to follow the medication of chronic patients, to correct false information and to provide correct information about COVID-19 disease, its prevention and treatment [13]. In addition, pharmacists inform patients about required hygiene measures to ensure infection control. This new global health problem led to an increase in their workload [11].

While many studies exist in the literature on the epidemiology, virology and contagion of COVID-19, studies on its psychological effects are relatively few. And those few are focusing more on health workers work- 
ing in hospitals such as doctors and nurses $[3,13]$. The experience of pharmacists has not been investigated enough, although they have been under serious risks while taking care of people [3]. The aim of this study is to measure the anxiety level of community pharmacists working in Istanbul during the COVID-19 pandemic and the factors that may affect it.

\section{Material and Methods}

The population of this cross-sectional study is community pharmacists working in all pharmacies in Istanbul $(\mathrm{N}=4912$ [14]). The sample size was calculated as 348 based on a $95 \%$ confidence level and $5 \%$ sampling error. Pharmacies were selected by a simple random sampling method from an open-sourced list [15] and telephone numbers of pharmacies are retrieved from the website of the Istanbul Chamber of Pharmacists [16]. Selected pharmacies were called from 8 September 2020 to 21 September 2020 by phone. Informed consent of participants was obtained verbally and recorded after the objective and methods had been fully explained. Questions were asked to those who volunteered for the study. If the phone was answered by someone other than the pharmacist, they are asked to hand the phone to the pharmacist. When phone calls were not answered or pharmacists were not available at the moment, they were called up to three times on different days and hours.

The data collection tool is a questionnaire that consists of questions about pharmacists' sociodemographic characteristics and work-related information, COVID-19-specific concerns, and the Beck Anxiety Inventory. Beck Anxiety Inventory is a scale consisting of 21 questions, which is used to measure the anxiety level of individuals. Its validity and reliability have been shown for the Turkish population [17]. Each question is scored between 0-3. 0 points represent "not at all", 1 point "mild", 2 points "moderate" and 3 points "severe". The severity of the anxiety experienced by the individuals is determined by the total score of these answers. According to the total score, 0-7 means "Minimal Anxiety", 8-15 means "Mild Anxiety", 16-25 means "Moderate Anxiety", and 26-63 means "Severe Anxiety" [17].
Determined based on previous studies, the independent variables of the current study consist of sociodemographic variables (age, gender, marital status, living alone) and work-related information (professional year, long-term working status, physical arrangement status, financial distress, financial or drug support status) $[4,18,19]$. The dependent variables consist of the concerns specific to COVID-19 (getting infected, infecting the family and friends, inability to access protective equipment, being excluded from the environment due to the profession) $[20,21]$ and the total score of the Beck Anxiety Inventory [18].

The data were analyzed by SPSS v25. Mean and standard deviation calculated for continuous variables, frequency and percentage for categorical variables. The differences in the mean anxiety scores between the groups were analyzed with statistical significance tests. For comparisons between two groups t-test for comparisons between more than two groups, one-way analysis of variance (ANOVA) and post-hoc Tukey test were used. The association between age, years of occupation and anxiety scores were evaluated with Pearson's correlation. Multiple linear regression analysis was performed to evaluate the effect of all variables on the anxiety score. The statistical significance level was accepted as 0.05.

This study was carried out with the permission of the Ministry of Health General Directorate of Healthcare on 27 August 2020 and the approval of the Istanbul Medipol University Non-Interventional Clinical Studies Ethics Committee dated 03 September 2020 (No: 43571).

\section{Results}

\subsection{Descriptive Statistics}

Data were collected from a total of $239(68.7 \%)$ participants. The mean age of the participants was $37.9 \pm 11.6$. The youngest was 23 and the oldest was 70 years old. The sociodemographic characteristics of the participants are summarized in Table 1. $135(56.5 \%)$ of the participants were women; 146 $(61.1 \%)$ of them were married. $45(18.8 \%)$ stated that they were living alone during the pandemic period. 
Table 1. Distribution of the participants by their sociodemographic characteristics.

\begin{tabular}{lcc}
\hline & $\mathbf{n}$ & $\mathbf{\%}$ \\
\hline Gender & 135 & 56.5 \\
Woman & 104 & 43.5 \\
Man & & \\
\hline Marital Status & 146 & 61.1 \\
Married & 80 & 33.5 \\
Single & 11 & 4.6 \\
Widow & 2 & 0.8 \\
Divorced & & \\
\hline Living alone & 192 & 80.3 \\
\hline No & 45 & 18.8 \\
Yes & 2 & 0.8 \\
Unknown & 239 & 100 \\
\hline Total & & \\
\hline
\end{tabular}

Among the participants, the number of years of experience in the profession was at least 1 and at most 45. The mean year of experience in the profession is $13.9 \pm 11$. The characteristics of the participants regarding the work during the COVID-19 pandemic are summarized in Table 2. 98 (41.0\%) of the participants stated that they had to work for longer hours, $234(97.9 \%)$ of them made physical arrangements in their pharmacies, $217(90.8 \%)$ stated that they received neither a financial nor supply support.

Table 3 shows the distribution of participants according to their level of concerns about COVID-19.74.5\% of the participants stated that the the concern about getting infected was " very " or "extreme", $83.3 \%$ of them stated that the the concern about infecting their family and friends was "very" or "extreme". 67.4\% of them stated that the the concern about not being able to reach the protective equipment was "not" or

Table 2. Distribution of participants by their work-related characteristics during the COVID-19 pandemic

\begin{tabular}{lcc}
\hline & n & \% \\
\hline Working longer hours & 98 & 41.0 \\
Making physical arrangements & 234 & 97.9 \\
$\begin{array}{l}\text { Experiencing financial problems } \\
\begin{array}{l}\text { Getting financial or medicine supply } \\
\text { support }\end{array}\end{array}$ & 133 & 55.6 \\
\hline
\end{tabular}

"little", and $63.2 \%$ of them stated that the the concern about social exclusion due to their profession was "not" or "little".

In response to the Beck Anxiety Inventory items, $39.3 \%$ of the participants stated that they experienced "nervousness", $34.7 \%$ "scared" and 22.6\% "fear of worst happening" at moderate and severe levels. Distributions for each inventory item are given in the supplementary material. The mean anxiety score of the participants was $9.4 \pm 10.6$ The distribution of the scale scores of the participants according to the anxiety levels formed by categorically grouping them is summarized in Table 4. 191 (79.9\%) of the participants who experienced "minimal" and "mild" levels of anxiety. Those expressing severe anxiety levels constitute $7.5 \%$ of the participants.

\subsection{Bivariate Analysis}

The mean anxiety score was significantly higher in women $(11.1 \pm 12.1)$ than in men participants $(7.3 \pm 7.9)(\mathrm{t}=2.9 ; \mathrm{p}=0.004)$.

No statistically significant correlation was found between anxiety score and age $(\mathrm{r}=0.02 \mathrm{p}=0.821)$ or professional year $(\mathrm{r}=0.05 \mathrm{p}=0.414)$. The mean anxiety scores of married ( $9.4 \pm 10.6)$, single $(8.4 \pm 8.5)$, divorced (13.5 \pm 2.1$)$ and widowed (16.0 \pm 20$)$ participants was not significantly different $(\mathrm{F}=1.79$, $\mathrm{p}=0.149$ ). Participants who were living alone (9.4 \pm 8.9$)$ or not $(9.5 \pm 11)(\mathrm{t}=0.06 \mathrm{p}=0.954)$; were working longer hours $(10.8 \pm 10.4)$ or not $(8.4 \pm 10.6)$ $(\mathrm{t}=1.72 \mathrm{p}=0.086)$; who made physical adjustments (9.5 \pm 10.7$)$ or not $(6.2 \pm 6.2)(\mathrm{t}=0.68 \mathrm{p}=0.496)$; who experienced financial distress $(10 \pm 9.6)$ or not $(8.7 \pm 11.7)(\mathrm{t}=0.97 \mathrm{p}=0.331)$; who received a support (6.7 \pm 7.6$)$ or not $(9.7 \pm 10.8)(\mathrm{t}=0.22 \mathrm{p}=0.215)$ were not differ significantly in terms of the mean anxiety score.

The mean anxiety scale scores according to the levels of the participants' concerns about COVID-19 are shown in Table 5. The mean anxiety scores were significantly different between participants with different levels of concerns of getting infected $(F=6,73$ $\mathrm{p}<0.001)$. Post-hoc analysis showed that it was due to the difference between those who were "extremely concerned" and those who were "little" or "moderately concerned". The mean anxiety scores were significantly different between participants with different levels of concerns about infecting the family and friends $(\mathrm{F}=4.96 \mathrm{p}=0.001)$. Post-hoc analysis showed 
Table 3. Distribution of participants by their concerns related to COVID-19

\begin{tabular}{|c|c|c|c|c|c|c|c|}
\hline & & Not & Little & Moderate & Very & Extreme & Total \\
\hline \multirow{2}{*}{$\begin{array}{l}\text { Concern about getting } \\
\text { infected }\end{array}$} & $\mathrm{n}$ & 4 & 18 & 39 & 74 & 104 & 239 \\
\hline & $\%$ & 1.7 & 7.5 & 16.3 & 31.0 & 43.5 & 100 \\
\hline \multirow{2}{*}{$\begin{array}{l}\text { Concern about infecting } \\
\text { family and friends }\end{array}$} & $\mathrm{n}$ & 6 & 5 & 29 & 58 & 141 & 239 \\
\hline & $\%$ & 2.5 & 2.1 & 12.1 & 24.3 & 59.0 & 100.0 \\
\hline \multirow{2}{*}{$\begin{array}{l}\text { Concern about not } \\
\text { being able to reach } \\
\text { protective equipment }\end{array}$} & $\mathrm{n}$ & 93 & 68 & 26 & 17 & 33 & 239 \\
\hline & $\%$ & 38.9 & 28.5 & 10.9 & 7.1 & 13.8 & 100.0 \\
\hline \multirow{2}{*}{$\begin{array}{l}\text { Concern about social } \\
\text { exclusion due to the } \\
\text { profession }\end{array}$} & $\mathrm{n}$ & 99 & 52 & 36 & 13 & 39 & 239 \\
\hline & $\%$ & 41.4 & 21.8 & 15.1 & 5.4 & 16.3 & 100.0 \\
\hline
\end{tabular}

Table 4. Distribution of participants by anxiety level groups

\begin{tabular}{lcc}
\hline Anxiety level group & $\mathbf{n}$ & $\mathbf{\%}$ \\
\hline Minimal & 131 & 54.8 \\
Mild & 60 & 25.1 \\
Moderate & 30 & 12.6 \\
Severe & 18 & 7.5 \\
Total & 239 & 100.0 \\
\hline
\end{tabular}

Table 5. The mean anxiety scale scores by the severity of COVID-19 related concerns of participants

\begin{tabular}{|c|c|c|c|c|c|}
\hline & n & Mean & SD & $\mathbf{F}$ & $\mathbf{p}$ \\
\hline \multicolumn{6}{|c|}{ Concern about getting infected } \\
\hline Not & 4 & 3.5 & 4.1 & 6.73 & $<0.001$ \\
\hline Little & 18 & 5.3 & 8.9 & & \\
\hline Moderate & 39 & 3.8 & 3.4 & & \\
\hline Very & 74 & 9.2 & 9.8 & & \\
\hline Extreme & 104 & 12.6 & 12.5 & & \\
\hline \multicolumn{6}{|c|}{ Concern about infecting family and friends } \\
\hline Not & 6 & 2.5 & 3.6 & 4.96 & 0.001 \\
\hline Little & 5 & 3.2 & 5.1 & & \\
\hline Moderate & 29 & 4.6 & 5 & & \\
\hline Very & 58 & 7.5 & 8.6 & & \\
\hline Extreme & 141 & 11.7 & 11.8 & & \\
\hline \multicolumn{6}{|c|}{ Concern about not being able to reach protective equipment } \\
\hline Not & 93 & 7.2 & 10.8 & 2.57 & 0.039 \\
\hline Little & 68 & 9.2 & 9.7 & & \\
\hline Moderate & 26 & 11.6 & 12.5 & & \\
\hline Very & 17 & 11.8 & 11.3 & & \\
\hline Extreme & 33 & 13.2 & 9 & & \\
\hline \multicolumn{6}{|c|}{ Concern about social exclusion due to the profession } \\
\hline Not & 99 & 6.9 & 9.4 & 3.12 & 0.016 \\
\hline Little & 52 & 9.4 & 9.5 & & \\
\hline Moderate & 36 & 11.8 & 15.2 & & \\
\hline Very & 13 & 10.3 & 10.2 & & \\
\hline Extreme & 39 & 13.1 & 8.5 & & \\
\hline
\end{tabular}


that it was due to the difference between those who were "extremely concerned" and those who were "moderately concerned". The mean anxiety scores were significantly different between participants with different levels of concerns of reaching the protective equipment $(\mathrm{F}=2.57 \mathrm{p}=0.039)$. Post-hoc analysis showed that it was due to the difference between those who were "extremely concerned" and those who were "not concerned". The mean anxiety scores were significantly different between participants with different levels of concerns of social exclusion due to profession $(\mathrm{F}=3.12 \mathrm{p}=0.016)$. Post-hoc analysis showed that it was due to the difference between those who were "extremely concerned" and those who did were "not concerned".

\subsection{Multiple Linear Regression Analysis}

Multiple linear regression analysis was performed to identify the determinants of the anxiety score. The variables could explain $19.5 \%\left(\mathrm{R}^{2}\right)$ of the variance in the anxiety score $(\mathrm{p}<0.001)$. As is seen in Table
6 , variables that determine the anxiety score at a statistically significant level are gender $(p=0.019)$ and the level of concern about getting infected $(\mathrm{p}=0.006)$. Being a woman increases the anxiety score by 3.12 points $(\beta=-0.15 t=-2.36)$. An increase in the concern about getting infected by one level increases the anxiety score by 2.39 points $(\beta=0.23 \mathrm{t}=2.79)$.

\section{Discussion}

\subsection{Anxiety Levels of Pharmacists}

The main purposes of this study were to measure the anxiety level of community pharmacists working in Istanbul during the COVID-19 pandemic and the factors that may affect it. The study showed that the mean anxiety score of community pharmacists in Istanbul was $9.4 \pm 10.6$. According to the interpretation of the Beck Anxiety Inventory, we can say that most of the participants did not show anxiety symptoms during the pandemic. $54.8 \%$ of the participants experience minimal anxiety and $25.1 \%$ mild anxiety.

Table 6. Results of multiple linear regression analysis: Determinants of anxiety scale score

\begin{tabular}{|c|c|c|c|c|c|c|c|}
\hline & \multirow[b]{2}{*}{ B } & \multirow[b]{2}{*}{ S.E. } & \multirow[b]{2}{*}{ Beta } & \multirow[b]{2}{*}{$\mathbf{t}$} & \multirow[b]{2}{*}{$\mathbf{p}$} & \multicolumn{2}{|c|}{ 95\% C.I. } \\
\hline & & & & & & Lower & Upper \\
\hline (Constant)a & 3.10 & 7.10 & & 0.44 & 0.663 & -10.90 & 17.10 \\
\hline Age & -0.29 & 0.19 & -0.32 & -1.55 & 0.122 & -0.66 & 0.08 \\
\hline Genderb & -3.12 & 1.33 & -0.15 & -2.36 & 0.019 & -5.74 & -0.51 \\
\hline Marital statusb & 1.89 & 1.18 & 0.12 & 1.60 & 0.111 & -0.44 & 4.21 \\
\hline Living alone & 0.28 & 1.78 & 0.01 & 0.16 & 0.873 & -3.22 & 3.79 \\
\hline Years in profession & 0.37 & 0.20 & 0.38 & 1.87 & 0.062 & -0.02 & 0.76 \\
\hline Working for longer hours & 2.22 & 1.42 & 0.10 & 1.56 & 0.119 & -0.58 & 5.01 \\
\hline Making physical arrangements & 0.62 & 4.60 & 0.01 & 0.13 & 0.894 & -8.45 & 9.68 \\
\hline Experiencing financial problems & 1.01 & 1.43 & 0.05 & 0.71 & 0.480 & -1.81 & 3.84 \\
\hline Getting financial or medicine supply support & -1.21 & 2.28 & -0.03 & -0.53 & 0.596 & -5.70 & 3.28 \\
\hline Concern about getting infected & 2.39 & 0.86 & 0.23 & 2.79 & 0.006 & 0.70 & 4.08 \\
\hline Concern about infecting family and friends & 0.26 & 0.98 & 0.02 & 0.27 & 0.790 & -1.67 & 2.19 \\
\hline Concern about not being able to reach protective equipment & 0.81 & 0.51 & 0.11 & 1.60 & 0.111 & -0.19 & 1.81 \\
\hline Concern about social exclusion due to the profession & 0.72 & 0.49 & 0.10 & 1.48 & 0.139 & -0.24 & 1.68 \\
\hline
\end{tabular}

a Dependent Variable: Anxiety Scale Score. b 0: Woman. 1: Man. c 0: Single 1: Married 2: Divorced 3: Widow 
The study conducted by Ayhan Başer et al. using the Beck Anxiety Inventory during the pandemic period points that $8.6 \%$ of the public show severe anxiety [18]. Our study indicates that $7.5 \%$ of the community pharmacists show severe anxiety. Various scales were used to measure the anxiety of healthcare professionals in the literature. In the study of Bohlken et al. during the pandemic period, the anxiety levels of doctors and nurses were measured by "Generalized Anxiety Disorder" (GAD-7), "Hamilton Anxiety Scale" (HAMA), "Self-rating Anxiety Scale" (SAS) and "Self-rating Fear Scale". (NRS) and very high anxiety was found in $2.2-14.5 \%$ of the participants [22]. In another study using SAS and GAD-7 scales, a severe anxiety level was found to be $2.17 \%$ among 53 healthcare professionals during the pandemic period [10]. However, it should be considered that the SAS scale can predict the prevalence of anxiety lower than other scales [23].

While studies before the COVID-19 pandemic estimated the global prevalence of anxiety as $7.3 \%$, in a meta-analysis covering studies during the COVID-19 period, the prevalence of anxiety was estimated to be $25 \%$ [23]. The findings of this study are consistent with the pre-pandemic global prevalence, which is lower than the global prevalence during the pandemic. This may be due to the fact that the research was conducted at a later stage of the pandemic. A different meta-analysis shows that anxiety reaches its highest level during the peak of the pandemic, and then decreases [23]. During the 2-week period in which this research was conducted, the daily average number of cases (patients) in Turkey was $1650.1 \pm 102.8$, and it has been approximately 5 months since the first national peak (5138) of the number of cases on 11 April 2020 [24].

\subsection{Factors Influencing Anxiety Level}

Bivariate analyzes show that being a woman pharmacist and having high levels of COVID-19 related concerns increase the mean anxiety score significantly. Generally, as the level of COVID-19 related concerns increases, the mean anxiety score increases. Multiple regression analysis indicated that being a woman increases anxiety score by 3.12 points, and each level of increase in the concern about getting infected increases anxiety score by 2.39 points.

A large number of studies conducted on healthcare professionals $[4,10]$ and the general population [19] before and during the pandemic, confirm that the anxiety levels of women pharmacists are higher than that of men [23]. This has been explained by reasons such as differences in brain chemistry and hormones, and that women experience feelings more open and stronger, and they are generally the caregiver in the family [23].

In this study, it was observed that concerns of getting infected and infecting the family and friends significantly increase the anxiety score. This is consistent with findings of previous studies either on health professionals and general society in the literature $[20,21,23]$. Community pharmacists need to feel safe for themselves and their loved ones so that they maintain their mental health while working. The fact that the participants are too much concerned about this issue highlights the need for interventions.

In previous studies, it was stated that the inability of pharmacists to access adequate protective equipment may be a threat in terms of anxiety [3,20,21]. In our study, most of the pharmacists were not concerned about not being able to reach the protective equipment. However, it was observed that the anxiety score of those who were highly concerned about not being able to reach the protective equipment was higher than the others. Therefore, it can be thought that this is a threat to the mental health of pharmacists, but as of the research period, pharmacists have largely solved this problem. Providing adequate protective equipment for health workers in future pandemics is required not only for their physical but also for their mental health. According to a study conducted on emergency physicians, physicians believe that the most effective measure to relieve their stress from COVID-19 is to improve access to personal protective equipment [21].

Similarly, the anxiety of stigmatization and exclusion due to their profession $[20,21]$ is experienced by a relatively small portion of the participants. Yet those who feel exclusion have a significantly higher anxiety score than those who do not.

The personal characteristics of the participants such as age, marital status, living alone, professional year, and professional characteristics such as working for a long time, making physical arrangements, experiencing financial difficulties, and getting support did not make a statistically significant difference in the anxiety score. The fact that age and marital status do not make a significant difference is compatible 
with studies conducted during the pandemic period in Turkey $[18,19]$. Although some studies in other countries show that younger people experience more anxiety during the pandemic period; it was thought that this could be due to their financial concerns and using social media as a source of health information [23]. The fact that pharmacists are expected to be stronger in terms of both financial and health information sources, may explain the lack of difference in anxiety scores between ages. Research in different countries reveals that the impact of marital status and cohabitation differs across cultures [23].

Elbeddini et al. associate the anxiety experienced by pharmacists with having to work for a long time [3]. In our study, however, there was no statistically significant difference in anxiety scores between those who had to work for a long time and those who did not. Almost all the participants state that they make physical arrangements in their pharmacies. This shows that community pharmacists in Istanbul have adapted to minimize the risk of transmission during the pandemic process. However, this situation makes it statistically difficult to determine the possible effect of physical arrangement on the level of anxiety. There is no study in the literature showing this effect. The finding that the effect of financial and supply support on anxiety levels can be explained by the fact that pharmacists have financial stability or have solved their problems over time, as in some other health care worker groups [23].

\subsection{Implications}

In terms of human resource planning in epidemic management, community pharmacists can be considered as a group with low anxiety levels and that quickly adapt to extraordinary conditions. Thus, they can take more active roles in preventing the epidemic.

Within the scope of this study, the most important factor determining the anxiety level of pharmacists during the pandemic period is the the concern about getting infected. Although almost all the pharmacists have taken the necessary measures in their pharmacy, they have concerns. Presenting scientific evidence to pharmacists about how effective those measures are to reduce the risk of disease transmission can relieve this concern. Sharing neighborhood-level epidemic information with community pharmacists and inclusion of them in local decision-making processes may have a positive effect on their anxiety levels.
Despite the measures being taken, the misbehavior of citizens in pharmacies may cause concern if getting infected for pharmacists. Effective health communication can reduce the anxiety of both parties.

Although the literature shows that this situation is not specific to the pandemic [23], the fact that women experience more anxiety than men can be taken into account in human resource planning during the pandemic and women pharmacists can be given priority in the future psychological support for health workers.

\subsection{Strengths And Limitations of the Study}

To our knowledge, this is the first study on anxiety in the Turkish literature that is focusing solely on pharmacists. Sample size, representative sampling (i.e., probability sampling), use of a validated and reliable scale, and multivariate analysis are the strengths of this study.

While evaluating the findings, it should be considered that this study is a cross-sectional study. This research shows the situation of community pharmacists at the time of the survey but does not provide information about the situation or causal relationships at earlier stages of the pandemic. Follow-up studies are needed to fully understand the impact of the pandemic. A comparison could not be made since there was not a previous study on the anxiety level of pharmacists before the pandemic. But this research can provide a benchmark for later studies in the pandemic. The lack of response from some pharmacists due to the intense working conditions can also be counted among the limitations. Yet, an acceptable proportion $(68.7 \%)$ of the target was reached. Another limitation is that the participants in the study were not evaluated whether they had an acute or chronic disease. Mental or physical health problems of individuals may affect the level of anxiety $[18,19,23]$. Since only actively working pharmacists are included in the study, only health problems that do not prevent the person from work may be a concern. Questioning the health status in future studies will make it possible to eliminate possible confounding effects.

\section{Conclusions}

In conclusion, this study showed that community pharmacists in Istanbul did not experience a high 
level of anxiety as of the 6th month of the pandemic; however, some concerns specific to COVID-19 are serious; these concerns have a significant effect on the anxiety score. This situation can be interpreted as promising in terms of public health, as it shows that pharmacists in Istanbul can cope with the pandemic psychologically. However, activities that address pharmacists' concerns about getting infected and infecting their families and friends may be important for maintaining the mental well-being of that important workers.

\section{References}

1. Lee AM, Wong JGWS, McAlonan GM, Cheung V, Cheung C, Sham PC, Chu C-M, Wong P-C, Tsang KWT, Chua SE: Stress and psychological distress among SARS survivors 1 year after the outbreak. Canadian Journal of Psychiatry. Revue Canadienne de Psychiatrie 2007, 52:233-240.

2. Torales J, O’Higgins M, Castaldelli-Maia JM, Ventriglio A: The outbreak of COVID-19 coronavirus and its impact on global mental health. The International Journal of Social Psychiatry 2020, 66:317-320.

3. Elbeddini A, Wen CX, Tayefehchamani Y, To A: Mental health issues impacting pharmacists during COVID-19. Journal of Pharmaceutical Policy and Practice 2020, 13:46.

4. Lai J, Ma S, Wang Y, Cai Z, Hu J, Wei N, Wu J, Du H, Chen T, Li R, Tan H, Kang L, Yao L, Huang M, Wang H, Wang G, Liu Z, Hu S: Factors Associated With Mental Health Outcomes Among Health Care Workers Exposed to Coronavirus Disease 2019. JAMA Network Open 2020, 3:e203976.

5. Chew NWS, Lee GKH, Tan BYQ, Jing M, Goh Y, Ngiam NJH, Yeo LLL, Ahmad A, Ahmed Khan F, Napolean Shanmugam G, Sharma AK, Komalkumar RN, Meenakshi PV, Shah K, Patel B, Chan BPL, Sunny S, Chandra B, Ong JJY, Paliwal PR, Wong LYH, Sagayanathan R, Chen JT, Ying Ng AY, Teoh HL, Tsivgoulis G, Ho CS, Ho RC, Sharma VK: A multinational, multicentre study on the psychological outcomes and associated physical symptoms amongst healthcare workers during COVID-19 outbreak. Brain, Behavior, and Immunity 2020, 88:559-565.

6. Kang L, Ma S, Chen M, Yang J, Wang Y, Li R, Yao L, Bai H, Cai Z, Xiang Yang B, Hu S, Zhang K, Wang G, Ma C, Liu Z: Impact on mental health and perceptions of psychological care among medical and nursing staff in Wuhan during the 2019 novel coronavirus disease outbreak: A cross-sectional study. Brain, Behavior, and Immunity 2020, 87:11-17.

7. Liu C-Y, Yang Y-Z, Zhang X-M, Xu X, Dou Q-L, Zhang W-W, Cheng ASK: The prevalence and influencing factors in anxi- ety in medical workers fighting COVID-19 in China: a crosssectional survey. Epidemiology and Infection 2020, 148:e98.

8. Hedima EW, Adeyemi MS, Ikunaiye NY: Community Pharmacists: On the frontline of health service against COVID-19 in LMICs. Research in Social \& Administrative Pharmacy 2021, 17:1964-1966.

9. Pappa S, Ntella V, Giannakas T, Giannakoulis VG, Papoutsi E, Katsaounou P: Prevalence of depression, anxiety, and insomnia among healthcare workers during the COVID-19 pandemic: A systematic review and meta-analysis. Brain, Behavior, and Immunity 2020, 88:901-907.

10. Shaukat N, Ali DM, Razzak J: Physical and mental health impacts of COVID-19 on healthcare workers: a scoping review. International Journal of Emergency Medicine 2020, 13:40.

11. Hoti K, Jakupi A, Hetemi D, Raka D, Hughes J, Desselle S: Provision of community pharmacy services during COVID-19 pandemic: a cross sectional study of community pharmacists' experiences with preventative measures and sources of information. International Journal of Clinical Pharmacy 2020, 42:1197-1206.

12. Hayden JC, Parkin R: The challenges of COVID-19 for community pharmacists and opportunities for the future. Irish Journal of Psychological Medicine 2020, 37:198-203.

13. Elbeddini A, Prabaharan T, Almasalkhi S, Tran C: Pharmacists and COVID-19. Journal of Pharmaceutical Policy and Practice $2020,13: 36$.

14. Türkiye İlaç ve Tıbbi Cihaz Kurumu (TİTCK). İlçe Eczane Kontenjanlar1; 2020 August 15. Available from: https:// www.titck.gov.tr/PortalAdmin/Uploads/UnitPageAttachment/ c1cfd8dc10483.pdf [Website].

15. Tüm İstanbul Eczaneleri; 2020 August 15. Available from: https://www.eczaneler.gen.tr/eczaneler/istanbul [Website].

16. İstanbul Eczacı Odasi; 2020 August 15. Available from: https://www.istanbuleczaciodasi.org.tr [Website].

17. Ulusoy M, Sahin NH, Erkmen H: The Beck anxiety inventory: psychometric properties. Journal of Cognitive Psychotherapy 1998, 12:163-172.

18. Ayhan Başer D, Çevik M, Gümüştakim Ş, Başara E: Assessment of individuals' attitude, knowledge and anxiety towards COVID-19 at the first period of the outbreak in Turkey: A web-based cross-sectional survey. International Journal of Clinical Practice 2020, 74:e13622.

19. Özdin S, Bayrak Özdin Ş: Levels and predictors of anxiety, depression and health anxiety during COVID-19 pandemic in Turkish society: The importance of gender. The International Journal of Social Psychiatry 2020, 66:504-511.

20. Giorgi G, Lecca LI, Alessio F, Finstad GL, Bondanini G, Lulli LG, Arcangeli G, Mucci N: COVID-19-Related Mental He- 
alth Effects in the Workplace: A Narrative Review. International Journal of Environmental Research and Public Health 2020, 17.

21. Rodriguez RM, Medak AJ, Baumann BM, Lim S, Chinnock B, Frazier R, Cooper RJ: Academic Emergency Medicine Physicians' Anxiety Levels, Stressors, and Potential Stress Mitigation Measures During the Acceleration Phase of the COVID-19 Pandemic. Academic Emergency Medicine 2020, 27:700-707.

22. Bohlken J, Schömig F, Lemke MR, Pumberger M, Riedel-Heller SG: COVID-19-Pandemie: Belastungen des medizinischen Personals. Psychiatrische Praxis 2020, 47:190-197.

23. Santabárbara J, Lasheras I, Lipnicki DM, Bueno-Notivol J, Pérez-Moreno M, López-Antón R, La Cámara C de, Lobo A, Gracia-García P: Prevalence of anxiety in the COVID-19 pandemic: An updated meta-analysis of community-based studies. Progress in Neuro-psychopharmacology \& Biological Psychiatry 2020, 109:110207.

24. Sağlık Bakanlığı. Genel Koronavirüs Tablosu; 2020 November 15. Available from: https://covid19.saglik.gov.tr/TR66935/genel-koronavirus-tablosu.html [Website]. 